\title{
Kronik Böbrek Yetmezliğinde Antioksidan Vitaminlerin İnflamasyon ve Oksidatif Stres Üzerine Etkisi
}

\author{
Effects of Antioxidant Vitamines on Inflammation and Oxidative Stress in Chronic Kidney \\ Disease
}

\author{
Feray Gençer Bingöl ${ }^{1}$, Makbule Gezmen Karadağ ${ }^{2}$
}

Geliş tarihi/Received: 07.02.2020 • Kabul tarihi/Accepted: 28.09.2020

\section{ÖZET}

Kronik böbrek yetmezliği (KBY), inflamasyonun ve oksidatif stresin sıklıkla eşlik ettiği bir süreç olarak bilinmektedir. Kronik böbrek yetmezliği hastalarında artan oksidatif stres düzeyleri, azalmış antioksidan savunma ve ortaya çıkan kronik inflamasyon kardiyovasküler hastalıklar başta olmak üzere birçok sağlık sorunu için risk faktörü olabilmektedir. $\mathrm{Bu}$ nedenle hastalarda antioksidan tedavinin uygun kullanımı oldukça önem taşımaktadır. Antioksidan vitaminlerin sürece etkisi değerlendirildiğinde, KBY hastalarında retinol bağlayıcı protein katabolizmasındaki azalmalar nedeniyle serum A vitamini konsantrasyonlarının sıklıkla yüksek olduğu düşünülmektedir. Buna bağlı olarak KBY hastalarına ek A vitamini suplemantasyonu önerilmemektedir. Diğer bir antioksidan olan C vitamininin, prooksidan etki gösterebilme ve oksalat oluşumunu artırma riski nedeniyle bu hastalara yönelik öneri konusu tartışmalıdır. Ancak diyaliz tedavisi alan hastalar değerlendirilirken C vitamininde gözlenen önemli kayıplar ve diyet kısıtlllıkları nedeniyle alımdaki azalmalar dikkate alınmalıdır. Kronik böbrek yetmezliği hastalarında E vitamininin birçok olumlu etkisi bildirilmekle birlikte suplemantasyonun dozu, süresi ve uygulama yolu gibi farklılıklar nedeniyle net öneri vermek mümkün olmamaktadır. Bununla birlikte özellikle E vitamini kaplı diyaliz membran kullanımının oksidatif stresi azaltabileceği düşünülmektedir. Kronik böbrek yetmezliği hastalarında antioksidan vitamin desteğine yönelik çalışmaların devam etmesi gerekmekle birlikte, hastaların diyet antioksidan vitamin alımlarının iyi değerlendirilmesi oldukça önem taşımaktadır.

Anahtar kelimeler: Antioksidan, inflamasyon, kronik böbrek yetmezliği, oksidatif stres, vitamin

\begin{abstract}
Chronic kidney disease (CKD) is often known as a process accompanied by inflammation and oxidative stress. Increasing oxidative stress levels, decreased antioxidant defense and chronic inflammation in CKD patients may be risk factors for many health problems, especially cardiovascular diseases. Therefore, proper use of antioxidant therapy is very important in these patients. When the effect of antioxidant vitamins is evaluated, serum vitamin A concentrations are often thought to be high in patients with CKD due to reductions in retinol-binding protein catabolism. Accordingly, vitamin A supplementation is not recommended for CKD patients. It is controversial to recommend vitamin C, another antioxidant, for these patients because of the pro-oxidant effects and risk of increasing oxalate formation. However, when evaluating patients receiving dialysis treatment, significant losses in vitamin $\mathrm{C}$ and decreases in intake due to dietary restrictions must be taken into attention. Although many positive effects of vitamin E have been reported in CKD patients, it is not possible to make clear

1. İletişim/Correspondence: Gazi Üniversitesi, Sağlık Bilimleri Fakültesi, Beslenme ve Diyetetik Bölümü, Ankara, Türkiye • E-posta: gencerferay@gmail.com

(D) https://orcid.org/0000-0001-5754-7208

2. Gazi Üniversitesi, Sağllk Bilimleri Fakültesi, Beslenme ve Diyetetik Bölümü, Ankara, Türkiye

(1) https://orcid.org/0000-0003-3202-3250
\end{abstract}


recommendations due to differences such as the dosage, duration and route of supplementation. However, it is thought that the use of vitamin E-coated dialysis membrane can alleviate oxidative stress. In patients with CKD, studies on antioxidant vitamin supplements are needed. In addition, the dietary antioxidant vitamin intake of the patients is very important to evaluate.

Keywords: Antioxidant, inflammation, chronic kidney disease, oxidative stress, vitamin

\section{GİRIŞ}

Günümüzde kronik böbrek yetmezliği (KBY) uluslararası kllavuzlar tarafindan, altında yatan nedene bakılmaksızın en az 3 ay boyunca glomerüler filtrasyon hizının (GFR) $60 \mathrm{~mL} / \mathrm{dk} / 1.73 \mathrm{~m}^{2}$ nin altına düşmesi ve/veya böbrek hasarının belirteçleri nedeniyle böbrek fonksiyonunun azalması olarak tanımlanmaktadır (1). Türkiye Nefroloji Derneği tarafından gerçekleştirilen Türkiye Kronik Böbrek Hastalığı Prevalansı Araştırması (Chronic Renal Disease in Turkey-CREDIT) ile ülkemizde genel erişkin popülasyonunda KBY prevalansı \%15.7 olarak bulunmuştur. CREDIT çalışmasında kadınlarda erkeklere oranla daha fazla KBY görüldüğü, yaşla birlikte riskin belirgin bir şekilde arttığı bildirilmiş̧ir (2).

Kronik böbrek yetmezliğinin temel bir özelliği olan inflamasyonun 1990'ların sonunda kardiyovasküler hastalıklar, protein enerji kaybı ve mortalite gibi birçok durumla ilişkili olduğu kabul edilmiştir $(3,4)$. Bunun yanında KBY hastalarında artan oksidatif stres düzeyleri ve azalmış antioksidan savunma durumu inflamasyon dahil olmak üzere çoklu etiyolojilere bağlı olarak ortaya çıkabilmektedir. Hastalarda antioksidan sistemin iyileştirilmesi ve antioksidan takviyelerin doğru kullanımı oldukça önem taşımaktadır (5).

Bu derleme, kronik böbrek yetmezliğinde antioksidan vitaminlerin inflamasyon ve oksidatif stres üzerine etkisini değerlendirmeyi amaçlamaktadır.

\section{Kronik Böbrek Yetmezliğinde İnflamasyon}

İnflamatuvar mekanizmalar, immün sistemin hümoral ve hücresel komponentlerinin katıldığı kompleks bir süreçtir. Vücutta birçok faktöre karşı inflamatuvar yanıt oluşturulduğu gibi, böbrekte ortaya çıkan doku hasarına bağlı da koruyucu inflamatuvar yanıt oluşturulmaktadır. Akut inflamatuvar yanıt böbrekte hücre ve dokuları hasardan korumak ve iyileşmeyi başlatmak için gerekli olup, oluşan pro-inflamatuvar yanit antiinflamatuvar yanıt ile düzenlenmektedir (6). Akut inflamasyonu başlatan ve sürdüren aracılar histamin, eikosanoidler, kompleman sistem, sitokinler, kinin gibi prokoagülanlar ve fibrinolitik moleküllerdir. Kronik inflamasyonda ise akut inflamatuvar yanit sürecinin basklanması gerçekleşmediği veya geciktiği için dokuda proinflamatuvar medyatörlerin birikimine ve doku hasarına neden olmaktadır. Dokuda hasar meydana gelse dahi inflamatuvar süreç devam edebilmektedir $(7,8)$.

İmmün sistemin bozulması ve inflamatuvar aktivasyona birçok faktör katkıda bulunabilmektedir. $\mathrm{Bu}$ durum primer bir hastalığa bağlı olarak ortaya çıkabileceği gibi genetik faktörlerden, epigenetik mekanizmalarda değişikliğe neden olan diyet, yaşam tarzı ve çevresel faktörlerden de etkilenmektedir (9). Bunun yanında, artmış sitokin üretimine ek olarak azalan böbrek klirensi dolaşımda artmış sitokin durumunun bir diğer nedeni olaraktanımlanmaktadır (10). Üremik toksinlerin KBY'de bağırsak disbiyozuna neden olabileceği, bakterilerin translokasyonunu ve bakteriyel bileşenlerin dolaşıma daha fazla katılmasına yol açabileceği ve bunun da sistemik inflamasyonu aktive edebileceği ileri sürülmektedir (11). Üremik ortam, yüksek düzeyde proinflamatuvar olan oksidatif stres ve karbonil strese de sebebiyet vermektedir (12).

Böbrek fonksiyonu bozulan hastalarda inflamasyona neden olan diğer durumlar ise sık enfeksiyon, oksidatif stres, periodontal hastalıklar, metabolik asidoz, D 
vitamini eksikliği ve diyalizle ilişkili faktörler olarak tanımlanmaktadır (9). Kronik böbrek yetmezliği olan hastalar ve özellikle diyaliz hastaları, inflamatuvar yanıt oluşturan sık enfeksiyon ve trombotik olaylara eğilim göstermektedir. Bu sık enfeksiyonlar özellikle kateter ile ilişkili kan dolaşımı enfeksiyonlarını, erişim bölgesi enfeksiyonlarını ve periton diyalizi hastalarında peritonit ataklarını içermektedir (13). D vitamininin immün sistem üzerinde önemli düzenleyici etkileri olduğu bilinmektedir. Kronik böbrek yetmezliği hastalarında aktif D vitamini formunun oluşturulamamasına ek olarak, birçok hastada normal serum $25(\mathrm{OH})$ D vitamini düzeylerinin de korunamadığı görülmektedir. $\mathrm{Bu}$ nedenle KBY ve son dönem böbrek yetmezliği olan hastalarda D vitamini eksikliği ile ilişkili immün fonksiyon bozukluğu, ortaya çıkan inflamatuvar yanitın nedenlerinden biri olarak öne sürülmektedir (14).

İnflamasyonun KBY hastalarındaki olumsuz sonuçlarından biri protein enerji kaybıdır. İnflamasyonun bu duruma neden olabileceği birkaç potansiyel mekanizma bulunmaktadır. Proinflamatuvar sitokinler doğrudan beyindeki etkisi ile anoreksiyaya neden olabilmektedir. Buna ek olarak inflamatuvar belirteçler, özellikle de interlökin-6 (IL-6), morbidite ve mortalitenin bir belirleyicisi olmasının yanında KBY'de besin alımında azalmaya neden olabilen depresyon ile ilişkili olabilmektedir. İnflamasyon bireylerin beslenmesini olumsuz yönde etkilemesinin yanında, dinlenme enerji harcamasında artış ile ilişkili olabilmektedir. Bağışıklık sisteminin, beyin ve kaslardan sonra vücutta başlıca enerji tüketicisi olması bu durumun temel sebebi kabul edilmektedir (9). Kronik böbrek yetmezliği hastalarında inflamasyonun başlıca diğer sonuçları da anemi, kemik-mineral bozukluğu ve özellikle çocuklarda büyüme geriliğidir (9). Şekil 1'de KBY hastalarında inflamasyona neden olan faktörler ve sonuçları özetlenmiştir $(9,13,14)$.

\section{Kronik Böbrek Yetmezliğinde Oksidatif Stres}

Oksidatif stres, reaktif oksijen türlerinin (ROT) üretim ve yıkım oranında oluşan dengesizlik olarak

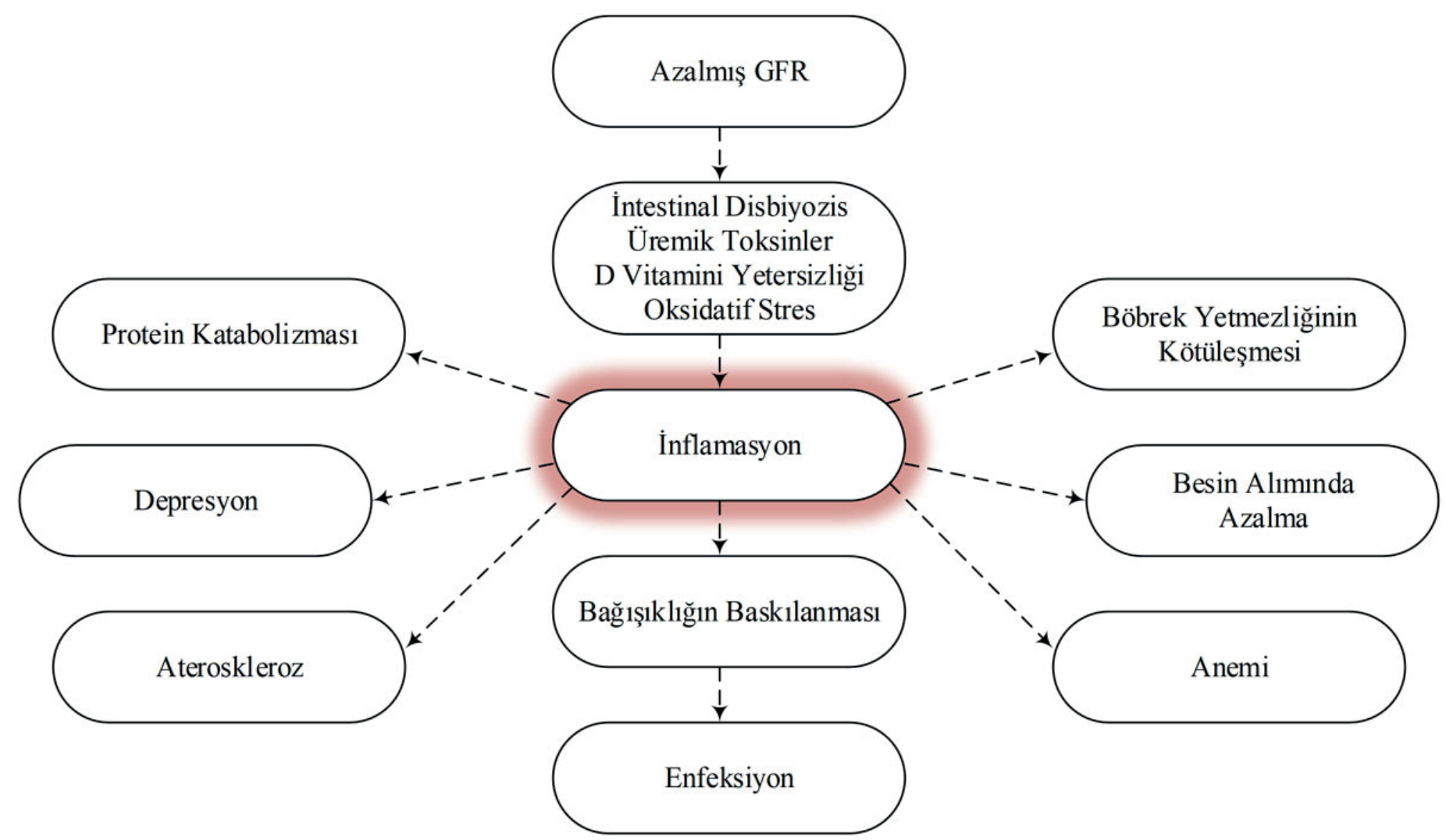

Şekil 1. Kronik böbrek yetmezliği hastalarında inflamasyona neden olan faktörler ve inflamasyonun sonuçları (9,13,14) 
tanımlanmaktadır. Normal şartlarda, süperoksit anyonları, hidrojen peroksit ve hidroksil radikali gibi reaktif oksijen türleri aerobik solunumda mitokondrideki enerji üretimi sırasında oksijenin azalması sonucu üretilmektedir. Reaktif oksijen türleri ve seviyeleri, süperoksit dismutaz, katalaz, glutatyon peroksidaz ve azalmış glutatyon, geçiş metal iyonları ve askorbik asit gibi endojen antioksidan savunmayı oluşturan diğer bileşenler gibi çeşitli enzim aktiviteleri aracılığıyla uzaklaştırılarak normal bir aralıkta tutulmaktadır (15). Bununla birlikte, aşırı ROT seviyeleri, proteinler, lipitler ve nükleik asitler gibi biyomoleküller ile etkileşerek hücresel hasara yol açabilmektedir ve bu nedenle doku fonksiyonu ve yapısı üzerinde olumsuz etkilere neden olabilmektedir. Renal disfonksiyon sıklıkla oksidatif stresle ilişkili kabul edilmektedir. Plazma F2-isoprostanlar, ileri oksidasyon protein ürünleri ve malondialdehit gibi farklı belirteçlerin seviyeleri, son dönem böbrek yetmezliği olan hastalar da dahil olmak üzere, çeşitli derecelerde renal fonksiyon bozukluğuna sahip hastalarda artış göstermektedir (16).

Kronik böbrek yetmezliğinde serbest oksijen radikali üreten başlıca oksidatif yollara yönelik araştırmalar devam etmektedir. Böbrekte, glomerüler hücreler, infiltran nötrofiller, monosit/makrofajlar ve trombositler tarafindan serbest oksijen radikali oluşturulduğu gösterilmiştir. Miyeloperoksidaz ile katalizlenen oksidatif olaylar, üremi ve hemodiyalizde, oksidatif stresin başlıca kaynakları olarak kabul edilmektedir ve bu olaylar doğrudan inflamasyonla ilişkili görülmektedir (17). Hemodiyaliz seanslarının başlamasından birkaç dakika sonra, diyalizör membranlarına ve diyalizata kanın ulaşması ile birlikte, trombositlerin ve beyaz kan hücrelerinin aktivasyonu ve ardından reaktif oksijen radikallerinin oluşumu tetiklenmektedir. Aktive olan beyaz kan hücrelerinden süperoksit ve hidrojen peroksit gibi radikaller ile birlikte miyeloperoksidaz plazmaya verilmektedir (18). Yüksek plazma miyeloperoksidaz değerleri oksidatif hasar oluşturabilen aktif beyaz kan hücrelerinin varlığını göstermesi açısından önemli bir parametre olarak düşünülmektedir (17). Kronik böbrek yetmezliği hastalarında artan oksidatif stres düzeyleri, kardiyovasküler risk faktörleri ve inflamasyon dahil olmak üzere çoklu etiyolojilere bağlı olabilmektedir. Bu nedenle, KBY hastalarında oksidatif stresi azaltmak için tedavi hedefi oldukça önem taşımaktadır. Kronikböbrekyetmezliği hastaları için antioksidan tedavide göz önünde bulundurulması gereken belirli zorluklar bulunmaktadır. Karşılaşılan bu zorluklara ve antioksidan tedavide dikkat edilecek hususlara Tablo 1'de yer verilmiştir (5).

\section{A Vitamini}

A vitamini, retinoidler olarak sınıflandırılmış yağda çözünen bileşiklerdir. İnsanlar besinler ile A vitamini öncüsü olan retinil esterler veya karotenoidleri almaktadır. Retinil esterler, retinole (retinoidlerin alkol formu), daha sonra retinale (aldehit formu) ve retinoik aside (asit formu) dönüşebilmektedir. Karotenoidler, $\beta$-karoten, $\alpha$-karoten ve $\beta$-kriptoksantin olup, en yaygin formu $\beta$-karotendir. Karotenoidler de retinole dönüşebilmektedir. Ancak, retinil esterlerin aktivitesinin yaklaşık \%50'sine sahiptir. A vitamini, retinol bağlayıcı proteine (RBP) bağlı şekilde kanda taşınmaktadır (19). Kronik böbrek yetmezliği gelişen hastalarda serum A vitamini konsantrasyonları sıklıkla artmaktadır. Potansiyel mekanizmalar,

Tablo 1. Kronik böbrek yetmezliği hastaları için antioksidan tedavide dikkat edilecek hususlar

\section{Oksidatif stresin etiyolojisinin saptanması}

» Etiyoloji kontrolünün sağlanamamasına bağlı oksidatif stresin antioksidan tedavisi sırasında yenilenebilmektedir.

\section{Antioksidan dozu ve uygulama yolu}

» Oksidatif stres seviyelerine göre en uygun antioksidan dozun ve yolun değerlendirilmesi gerekmektedir.

\section{Yüksek oksidatif stres varlığı}

» Yüksek oksidatif stres varlığında birçok antioksidan, oksidatif strese neden olabilen pro-oksidan maddelere dönüşebilmektedir. 
RBP’lerin katabolizmasının azalmasını içermektedir. Serum A vitamini konsantrasyonu, serum kreatinin düzeyinin artışına bağlı olarak yükselmeye başladığı için KBY hastaları için ek vitamin desteğine gerek duyulmamaktadır. $\mathrm{Bu}$ nedenle KBY hastalarında Önerilen Günlük Alım Miktarı (Recommended Dietary Allowance-RDA) önerileri kabul görmekte ve RDA önerilerinin altında alım olmadığı sürece takviye önerilmemektedir (20).

Yapılan bir çalışmada, $55 \mathrm{KBY}$ ve 21 sağlıklı bireyin plazma ve idrar retinoid ve retinol bağlayıcı protein 4 (RBP4) ölçümü yapılmıştır. Kronik böbrek yetmezliği hastalarının RBP4 veretinol seviyelerikontrolgrubuna göre iki kat daha yüksek bulunmuştur. Plazma retinol seviyeleri ve RBP4 ile GFR arasında anlamlı negatif ilişki olduğu ve KBY hastalarında dolaşımda all trans retinoik asit seviyelerinin arttı̆̆ edilmiştir. Araştırmacılar artışın artan hepatik RBP4 sentezi, retinil ester hidrolizi ve RBP4-retinol hepatik sekresyonu nedeniyle olabileceğini bildirmişlerdir (21). Yapılan prospektif kohort bir çalışmada ise beş yılın sonunda 2152 katılımcı arasında 290 katılımcı da (\%13.5) böbrek fonksiyon bozukluğu (GFR \%15 azalma) ortaya çıkmıştır. Yüksek serum karotenoid düzeyi ile böbrek fonksiyon kaybı arasında negatif ilişki olduğu ve KBY için koruyucu etkisinin olduğu bildirilmiştir (22).

\section{Vitamini}

C vitamini veya askorbik asit, en fazla iki elektron vererek diğer bileşiklerin oksidasyonunu inhibe edebilen ve bu süreçte oksidasyona uğrayan hidrofilik, 6-karbonlu bir laktondur. Askorbik asit bir elektron verdiğinde semi-hidroaskorbik asit olarak bilinen serbest bir radikal haline gelmektedir. İkinci bir elektron verdikten sonra yarı-hidroaskorbik asit, dehidroaskorbik aside dönüşmektedir. $\mathrm{Bu}$ işlem oksidasyondan sonra hücresel hasar tehdidini azaltıp, vücuttaki serbest radikalleri temizlemektedir $(15,20)$.

C vitamini hem antioksidan hem de prooksidan olarak hareket edebilmektedir. Doğrudan oksidan temizleme özellikleri nedeniyle genellikle koruyucu bir antioksidan olarak kabul edilmektedir. Ancak C vitamini $\mathrm{Fe}^{+3}$ 'ü $\mathrm{Fe}^{+2}$ 'ye dönüştürmesi ve $\mathrm{ROT}$ oluşumunu katalize etmesi nedeniyle prooksidan olarak da görev yapmaktadır (23). Diğer yandan C vitamininin, hemodiyaliz hastalarında anemi belirtilerini iyileştirdiği gösterilmektedir (24). Bir koantioksidan olarak kabul edilen $C$ vitamini, lipitte çözünebilen radikallerin temizlenmesi yoluyla üretilen alfa tokoferoksil radikalinden alfa tokoferol üretebilmektedir. Özellikle diyaliz tedavisi sırasında verilen yüksek doz C vitamini uygulaması, lipid peroksidasyonunda artışı engelleyebilmektedir. $\mathrm{Bu}$ durum endojen E vitamini rejenerasyon oranının artması ile ilişkilendirilmektedir (23).

Hemodiyaliz hastalarının normal popülasyona kıyasla genellikle daha düşük bir plazma $C$ vitamini seviyesine sahip oldukları iyi bilinmektedir. Düşük plazma C vitamini seviyesi, meyve ve sebze alımı ile ilgili diyet kısıtlamalarına, diyaliz prosedürü sırasında üremide bozulmuş metabolizmaya, artan inflamasyon, oksidatif stres ve sekonder hiperparatroidizme bağlı olabilmektedir. Bir başka olası açıklama, C vitamini metabolizması büyük ölçüde glutatyona bağlı olduğu ve diyaliz hastalarında belirgin bir glutatyon eksikliği söz konusu olduğu için askorbatın C vitamininin okside olmuş şekli olan dehidroaskorbattan geri dönüşümü için enzimatik veya enzimatik olmayan mekanizmaların bozulmasıdır (25). Diyaliz seansı sırasında askorbik asit kaybının yaklaşık \%2840 olduğu hatta intradiyalitik kayıpların \%60’lara kadar ulaşabileceği gösterilmiştir. Diyaliz seansında büyük oranda $\mathrm{C}$ vitamini kaybının yanında vitamin dehidroaskorbik aside kolayca oksitlenebilmektedir (23). Hemodiyaliz hastalarında C vitamini kaybının değerlendirildiği bir çalışmada, bir diyaliz seansı ile ortalama \%60 kayıp olduğu ve suplemantasyon alan hastalarda almayanlara göre diyaliz öncesi $C$ vitamini düzeyi anlamlı derecede yüksek bulunmuştur (26).

Oksalat askorbik asidin bir metabolitidir. Böbrek yetmezliği olan hastalarda askorbik asit suplemantasyonu idrar oksalat ve serum oksalat düzeyini artırabilmektedir. Plazma oksalat seviyelerinin $50 \mathrm{mcg} / \mathrm{L}$ ’nin üzerine çıkması retina, 
eklem ve kalp dokusunda birikime yol açabilmektedir. Hiperoksaloz riski nedeniyle KBY hastalarında yüksek C vitamini dozları tavsiye edilmemektedir $(20,23)$. Bu endişelerden dolayı, diyaliz almayan KBY hastaları için Böbrek Yetmezliği olan Avustralyalıların Bakımı (Caring for Australasians with Renal Impairment-CARI) kllavuzu suplemantasyonun 60 mg/günü geçmemesini, Avrupa Klinik Nütrisyon ve Metabolizma Derneği (European Society for Clinical Nutrition and Metabolism-ESPEN) kılavuzu ise 30-60 $\mathrm{mg} /$ gün arasında C vitamini takviyesi önermektedir $(27,28)$.

Zhang ve arkadaşlarının (29) yaptığı bir çalışmada, üç ay boyunca $200 \mathrm{mg} /$ ün C vitamini takviyesi yapılmış ve serum $C$ vitamini düzeylerinde yükselme, yüksek hassasiyetli CRP düzeylerinde düşme ve prealbümin düzeylerinde anlamlı artış görülmüştür. Ancak suplemantasyon kesildikten sonra tüm belirteçler başlangıçtaki düzeylerine dönmüştür. Ferretti ve arkadaşlarının (30) yaptığı bir çalışmada, altı ay boyunca 33 hemodiyaliz tedavisi alan hastaya haftada 3 kere $500 \mathrm{mg}$ intravenöz C vitamini uygulaması yapılmıştır. Uygulama sonrasında suplemantasyon yapılan hastalarda, AGE ürünlerinde ve lipit hidroperoksitlerinde azalma ve paraoksonaz-1 aktivitesinde artış görülmüştür. Yapılan başka bir çalışmada, 109 hemodiyaliz hastasına ilk üç ay boyunca oral olarak $360 \mathrm{mg} /$ hafta sonraki üç ay $1500 \mathrm{mg} /$ hafta C vitamini verilmiştir. Çalışmanın 7 . ve 9. ayları arasındaki üç ayda ise suplemantasyon kesilmiştir. Serum askorbik asit düzeyi ve plazma malondialdehit düzeyi 3. ve 6. ayda anlamlı olarak yükselmiştir. $\mathrm{C}$ vitamini suplemantasyonu kesildikten sonra belirteçler başlangıç düzeyine geri dönmüştür (31). Hemodiyaliz hastalarında C vitamininin oksidatif stres üzerine etkisinin değerlendirildiği 11 çalışmadan oluşan sistematik derlemede ise 4 çalışmada olumlu etki, 3 çalışmada ise olumsuz etki bildirilirken, 4 çalışmada hiçbir etki bildirilmemiştir (32).

Çalışmalar C vitamini için farklı ve çelişkili sonuçlar ortaya koymaktadır (29-32). Bunun nedeni, çalışma popülasyonlarının farklı yaşa, diyaliz süresine, sigara içme durumuna ve diyabete sahip olması, verilen $\mathrm{C}$ vitamininin dozunun, süresinin, veriliş yolunun ve çalışmalarda kullanılan oksidatif stres ve inflamasyon belirteçlerinin farklı olması olabilir. Birçok klinisyen, böbrek yetmezliği olan hastaların dokularında oksalat birikimini göz önünde bulundurarak, C vitamini alımını 60-100 mg/gün aralığında tutmaktadır. Diğer taraftan diyaliz tedavisi sırasında ortaya çıkan C vitamini kayıpları nedeniyle, 100-200 mg/gün oral C vitamini veya haftada üç gün diyaliz seansı sonrası 300-500 mg intravenöz C vitamininin yeterli ve güvenli olduğu görülmektedir (33).

\section{E Vitamini}

E vitamini, alfa, beta, gama, sigma tokoferol ve tokotrienolleri içeren, sekiz molekülden oluşan bir grubu kapsamaktadır. Biyolojik olarak en aktif formu, alfa tokoferoldür. Alfa tokoferol, hücre zarında bulunan uzun zincirli çoklu doymamış yağ asitlerinin bütünlüğünü ve biyoaktivitelerini korumaktadır. Özellikle, E vitamini lipit yapılarını peroksidasyondan korumaktadır ve oksidatif modifikasyona karşı düşük dansiteli lipoproteinin (LDL) direncini arttırmaktadır. $\mathrm{Bu}$ olay $\mathrm{E}$ vitamininin aterosklerozun önlenmesinde potansiyel bir etkisinin olduğunu düşündürmektedir. Ayrıca, E vitamini mitokondriyal hidrojen peroksit oluşumunu azaltmaktadır ve inflamasyon ve fibrozis ile ilişkili genlerin ekspresyonunu düzenlemektedir $(25,34)$.

Glomerüler membran bütünlüğünün korunması renal fonksiyon için çok önemlidir ve biyolojik membranlar temel olarak lipofilik antioksidan E vitamininin alfa tokoferol formu tarafindan oksidatif bozulmaya karşı korunmaktadır. E vitamini ayrıca membran geçirgenliğini ve akışkanlığını fiziksel olarak stabilize edici etki göstermektedir. Antioksidan fonksiyonlarını, zararlı endojen lipid düşürücü enzimlerden membranların korunmasını, nötr endotelyal vazoaktivitenin desteklenmesini, nötrofil kemotaksisinin ve doku infiltrasyonunun azaltılması ve trombosit agregasyonunun inhibisyonunu sağlayarak göstermektedir. Bu etkileri nedeniyle E vitamininin güçlü anti-inflamatuvar özelliklere sahip olduğu düşünülmektedir. Ek olarak oksidatif 
strese bağll apoptozu önleyebilmektedir. Hücrelerde antioksidan etkisinin daha güçlü olması için ikinci bir E vitamini formunun (gama tokoferol) varlığına gerek duyulmaktadır (35).

Kronik böbrek yetmezliği hastalarında plazma E vitamini düzeyleri, diyet $\mathrm{E}$ vitamini alımını azalttığı durumlarda bile, sağlıklı bireylerden farklı görülmemektedir. E vitamini metaboliti, karboksietil hidroksikromans (CEHC), böbrek fonksiyonlarında azalma ile özellikle 3. evreden sonra serumda önemli ölçüde artmaktadır. Üremik KBY hastalarında bu metabolitin birikiminin $\mathrm{E}$ vitamini işlevlerini etkileyebileceği öne sürülmektedir. $\mathrm{Bu}$ nedenle özellikle 2-5. evre KBY hastalarında RDA önerileri geçerli kabul edilmektedir (20).

E vitamininin hemodiyaliz tedavisi alan KBY'li hastalarda oksidan ve antioksidan durum üzerindeki etkisinin değerlendirildiği bir çalışmada, kontrol grubu ile karşılaştırıldığında, serum malondialdehit seviyesinin önemli derecede yüksek, eritrosit süperoksit dismutaz ve katalaz aktivitesine ek olarak serum nitrik oksit, serum vitamin E ve plazma vitamin C düzeylerinin önemli derecede düşük olduğu hem diyaliz öncesi hem de diyaliz sonrası sonuçlarda görülmüştür. Bunun yanında hemodiyaliz alan hastalara iki ay boyunca günde 400 IU E vitamini suplemantasyonu yapılmış, suplemantasyon sonucunda serum malondialdehit seviyesinin önemli derecede düştüğü, eritrosit süperoksit dismutaz ve katalaz aktivitesine ek olarak serum nitrik oksit, vitamin $\mathrm{E}$ ve vitamin $\mathrm{C}$ düzeylerinin anlamlı derecede arttığı bildirilmiştir (36).

Saran ve arkadaşlarının (37) yaptığı bir çalışmada, sekiz KBY hastası ve altı sağlıklı kontrole 800 IU E vitamini suplemantasyonu yapılmıştır. Sekiz haftalık suplemantasyondan sonra KBY hastalarının altısında plazma asimetrikdimetilarginin (ADMA) düzeyi azalma göstermiştir. E vitamini tedavisi ile plazma F2isoprostanlar ise anlamlı değişiklik göstermemiştir.

Yapılan başka bir çalışmada, 29 hemodiyaliz hastası randomize iki gruba ayrılmış ve 15 hastanın olduğu bir gruba beş hafta boyunca günde $400 \mathrm{mg} \mathrm{E}$ vitamini verilmiştir. Hemodiyaliz hastalarında CRP seviyeleri sağlıklı kontrollere göre anlamlı düzeyde yüksek bulunmuştur. Suplemantasyon sonucunda hastaların serum CRP seviyelerinde anlamlı değişiklik görülmemiştir (38).

E vitamininin oksidatif stres üzerine etkisinin değerlendirildiği bir sistematik derlemede, 25 çalışmanın 20'sinde alfa tokoferol takviyesinin oksidatif stresi azalttığ görülen 20 çalışmada verilen ortalama dozun 500 mg (en düşük 15 IU en fazla 1200 IU), ortalama etki süresinin ise sekiz hafta olduğu görülmektedir (32).

Çalışmalarda genellikle alfa tokoferolün etkisi değerlendirilmekle birlikte (32,36-38), alfa ve gamma tokoferolün birlikte etkilerinin değerlendirildiği bir çalışmada, özellikle altı gün boyunca günlük $600 \mathrm{mg}$ gama tokoferol uygulamasiyla hemodiyaliz tedavisi alan hastalarda kontrol grubuna göre serum CRP düzeylerinin anlamlı düzeyde düştüğü gösterilmiştir (39).

Yüksek oral dozlarda E vitamini suplemantasyonu (1500-3200 IU/gün), küçük ve iyi tolere edilebilen gastrointestinal yan etkiler nedeniyle zararsız görünmektedir ve dolaşımdaki seviyeyi normal miktarın 2-4 katına artırabilmektedir. E vitamini, insanlarda özellikle patogenezinde oksijensiz radikalleri ve oksidatif stresi içeren Friedreich ataksisi, Alzheimer, Parkinson, Huntington gibi sinir sistemi hastalıklarının tedavisinde denenmiş ve başarılı sonuçlar elde edilmiştir. İnsanlarda böbrek yetmezliğini yavaşlatmaya yardımcı olabilecek E vitamini için optimal dozun 300-700 IU/gün arasında olabileceği düşünülmektedir. Tedavi edici bu miktarın oksidatif stresin neden olduğu uzun süreli dejeneratif hastalıkları önlemek için yeterli olacağı ve yan etkilerin oluşturacak eşik değerin altında olduğu düşünülmektedir (35).

$\mathrm{Bu}$ vitaminle ilgili olarak çalışılan diğer bir konu da E vitamini kaplı diyaliz membranlarıdır. Evitamini kaplı diyaliz membranların değerlendirildiği 15 çalışmayı 
inceleyen bir sistematik derleme ve meta analizde, tiyobarbitürik asit reaktif maddeler (TBARS), okside LDL, CRP ve IL-6 değerlerinde anlamlı azalmalar görüldüğü ve E vitamini kaplı diyaliz membranların oksidatif stres ve inflamasyon üzerinde olumlu etki gösterdiği belirtilmiştir (40).

\section{SONUÇ VE ÖNERİLER}

Kronik böbrek yetmezliği olan hastalarda oksidatif stres ve inflamasyon sıklıkla görülen bir tablo olup, özellikle aterosklerozun temelini oluşturmaktadır. Bu aşamada antioksidanlar ve antioksidan vitaminlerin etkinliği ön plana çıkmaktadır. A vitamininin bu hasta grubunda oksidatif stres ve inflamasyon üzerine etkisi açık değildir. Bu hastalarda özellikle serum A vitamini seviyelerinde yükselmeler görülebilmektedir. $\mathrm{Bu}$ nedenle A vitamini alımının sağlıklı bireylerde önerilen gereksinmeleri geçmesi istenmemektedir. C vitamininin bu hastalarda olumlu etkileri görülmekle birlikte, oksalat oluşumunda artış ve prooksidan etki göstermesi nedeniyle önerilen doz miktarları tartışmalıdır. Hastaların diyetsel kısıtlılıkları ve diyaliz alan hastalarda oluşan kayıplar göz önüne alındığında C vitamini için yetersiz alım riski bulunmaktadır. E vitamini bu hastalarda en çok çalışılan ve olumlu etkisi görülen antioksidan vitamin olmakla birlikte oral ve intravenöz uygulama farklılıkları ve yüksek doz uygulamalarda görülen olumsuz sonuçlar öneri yapmayı zorlaştırmaktadır. Ancak diyaliz hastalarında çalışılan E vitamini kaplı membranların oksidatif stres ve inflamasyon belirteçleri üzerinde oldukça etkili olduğu görülmektedir. Kronik böbrek yetmezliği hastalarında antioksidan tedavisine yönelik çalışmaların devam etmesi gerekmekle birlikte, hastaların diyet antioksidan vitamin alımlarının iyi değerlendirilmesi oldukça önem taşımaktadır. Diyet alımı yetersiz hastaların özellikle $C$ ve $E$ vitamini için gereksinimlerinin karşılanması hastaların oksidan ve inflamatuvar belirteçlerinde olumlu katkı sağlayabilir.

Çıkar çatışması - Conflict of interest: Yazarlar çıkar çatışması olmadığını beyan ederler. - The authors declare that they have no conflict of interest.

\section{KAYNAKLAR}

1. KDIGO Group. KDIGO 2012 Clinical Practice Guideline for the evaluation and management of chronic kidney disease. Kidney Int Suppl. 2013;3:1-150.

2. Süleymanlar G, Utaş C, Arınsoy T, Ateş K, Altun B, Altiparmak MR, et al. A population-based survey of chronic renal disease in Turkey-the CREDIT study. Nephrol Dial Transplant. 2010;26(6):1862-71.

3. Zimmermann J, Herrlinger S, Pruy A, Metzger $\mathrm{T}$, Wanner C. Inflammation enhances cardiovascular risk and mortality in hemodialysis patients. Kidney Int. 1999;55(2):648-58.

4. Stenvinkel P, Heimbürger O, Paultre F, Diczfalusy U, Wang T, Berglund L, et al. Strong association between malnutrition, inflammation, and atherosclerosis in chronic renal failure. Kidney Int. 1999;55(5):1899-911.

5. Chen J, Siriki R. Antioxidants therapy for patients with chronic kidney disease: A question of balance. Am J Nephrol. 2015;42(4):318-9.

6. Silverstein DM. Inflammation in chronic kidney disease: Role in the progression of renal and cardiovascular disease. Pediatr Nephrol. 2009;24(8):1445-52.

7. Carrero JJ, Yilmaz MI, Lindholm B, Stenvinkel P. Cytokine dysregulation in chronic kidney disease: How can we treat it? Blood Purif. 2008;26(3):291-9.

8. Ülger Öztürk N, Nergiz-Unal R. Kronik böbrek hastalığında renal inflamasyon ve bazı güncel diyet bileşenleri ilişkisi. Turkish Nephrol Dial Transplant. 2018;27(01):14-25.

9. Akchurin OM, Kaskel F. Update on inflammation in chronic kidney disease. Blood Purif. 2015;39:84-92.

10. Rosengren BI, Sagstad SJ, Karlsen TV, Wiig H. Isolation of interstitial fluid and demonstration of local proinflammatory cytokine production and increased absorptive gradient in chronic peritoneal dialysis. Am J Physiol Physiol. 2013;304(2):198-206.

11. Castillo-Rodríguez E, Pizarro-Sánchez S, Sanz AB, Ramos AM, Sanchez-Niño MD, Martin-Cleary C, et al. Inflammatory cytokines as uremic toxins: "ni son todos los que estan, ni estan todos los que son.” Toxins (Basel). 2017;9(4):1-21.

12. Aveles PR, Criminácio CR, Gonçalves S, Bignelli AT, Claro LM, Siqueira SS, et al. Association between biomarkers of carbonyl stress with increased systemic inflammatory response in different stages of chronic kidney disease and after renal transplantation. Nephron - Clin Pract. 2010;116(4):294-9.

13. Nassar GM. Preventing and treating inflammation: Role of dialysis access management. Semin Dial. 2013;26(1):28-30.

14. Williams S, Malatesta K, Norris K. Vitamin D and chronic 
kidney disease. Ethn Dis. 2009;19:416-27.

15. Daenen K, Bammens B. Oxidative stress in chronic kidney disease. Pediatr Nephrol. 2018;34(6):975-91.

16. Cachofeiro V, Goicochea M, De Vinuesa SG, Oubĩa P, Lahera V, Lũo J. Oxidative stress and inflammation, a link between chronic kidney disease and cardiovascular disease. Kidney Int. 2008;74:4-9.

17. Yazıcı C, Köse K. Kronik böbrek yetmezliğinde oksidatif stres ve "biyomarkı" ları. Türk Nefroloji Diyal ve Transplant Derg. 2004;13(3):117-24.

18. Liakopoulos V, Roumeliotis S, Gorny X, Dounousi E, Mertens PR. Oxidative stress in hemodialysis patients: A review of the literature. Oxid. Med. Cell. Longev. 2017:1-22

19. Chazot C, Jean G, Kopple JD. Can outcomes be improved in dialysis patients by optimizing trace mineral, micronutrient, and antioxidant status?: The impact of vitamins and their supplementation. Semin Dial. 2016;29(1):39-48.

20. Steiber AL, Kopple JD. Vitamin status and needs for people with stages 3-5 chronic kidney disease. J Ren Nutr. 2011;21(5):355-68.

21. Jing J, Isoherranen N, Petrie I, Kestenbaum BR, Yeung CK. Chronic kidney disease alters vitamin a homeostasis via effects on hepatic RBP4 protein expression and metabolic enzymes. Clin Transl Sci. 2016;(9):207-15.

22. Hirahatake KM, Jacobs DR, Gross MD, Bibbins-domingo KB, Shlipak MG, Mattix-kramer H, et al. The association of serum carotenoids, tocopherols, and ascorbic acid with rapid kidney function decline: The coronary artery risk development in young. J Ren Nutr. 2019;29(1):65-73.

23. Jankowska M, Rutkowski B, Dębska-Ślizień A. Vitamins and microelement bioavailability in different stages of chronic kidney disease. Nutrients. 2017;9:282-9.

24. Deved V, Poyah P, James MT, Tonelli M, Manns BJ, Walsh $\mathrm{M}$, et al. Ascorbic acid for anemia management in hemodialysis patients: A systematic review and metaanalysis. Am J Kidney Dis. 2009;54(6):1089-97.

25. Signorini L, Granata S, Lupo A, Zaza G. Naturally occurring compounds: New potential weapons against oxidative stress in chronic kidney disease. Int J Mol Sci. 2017;18:1481.

26. Sirover WD, Liu Y, Logan A, Hunter K, Benz RL, Prasad D, et al. Plasma ascorbic acid concentrations in prevalent patients with end-stage renal disease on hemodialysis. J Ren Nutr. 2019;25(3):292-300.

27. Cano NJM, Aparicio M, Brunori G, Carrero JJ, Cianciaruso
B, Fiaccadori E, et al. ESPEN guidelines on parenteral nutrition: Adult renal failure. Clin Nutr. 2009;28(4):40114.

28. Voss D. Vitamins in pre-dialysis patients. CARI Guidelines. Nephrol. 2005;10:177-230.

29. Zhang K, Li Y, Cheng X, Liu L, Bai W, Guo W, et al. Crossover study of influence of oral vitamin C supplementation on inflammatory status in maintenance hemodialysis patients. BMC Nephrol. 2013;14:252.

30. Ferretti G, Bacchetti T, Masciangelo S, Pallotta G. Lipid peroxidation in hemodialysis patients: Effect of vitamin C supplementation. Clin Biochem. 2008;41:381-6.

31. De Vriese AS, Borrey D, Mahieu E, Claeys I, Stevens L, Vanhaeverbeke A, et al. Oral vitamin $\mathrm{C}$ administration increases lipid peroxidation in hemodialysis patients. Nephron - Clin Pract. 2008;108:28-34.

32. Coombes JS, Fassett RG. Antioxidant therapy in hemodialysis patients: A systematic review. Kidney Int. 2012;81:233-46.

33. Zhang KY, Zuo L. Vitamin C supplementation in patients on maintenance dialysis. World J Clin Urol. 2014;3(3):344-50.

34. Cho KS, Ko IK, Yoo JJ. Bioactive compounds for the treatment of renal disease. Yonsei Med J. 2018;59(9):1015.

35. Fryer MJ. Vitamin $\mathrm{E}$ as a protective antioxidant in progressive renal failure. Nephrology. 2000;5(1-2):1-7.

36. Bhogade R, Suryakar A, Joshi N, Patil R. Effect of vitamin E supplementation on oxidative stress in hemodialysis patients. Indian J Clin Biochem. 2008;23(3):233-7.

37. Saran R, Novak JE, Desai A, Abdulhayoglu E, Warren JS, Handelman GJ, et al. Impact of vitamin E on plasma asymmetric dimethylarginine (ADMA) in chronic kidney disease (CKD): A pilot study. Nephrol Dial Transplant. 2003;18:2415-20.

38. Hodkova M, Dusilova-sulkova S, Kalousova M, Soukupova J, Zima T, Mikova D, et al. Influence of oral vitamin $\mathrm{E}$ therapy on micro-inflammation and cardiovascular disease markers in chronic hemodialysis patients. Ren Fail. 2006;28(5):395-9.

39. Himmelfarb J, Kane J, McMonagle E, Zaltas E, Bobzin S, Boddupalli S, et al. Alpha and gamma tocopherol metabolism in healthy subjects and patients with endstage renal disease. Kidney Int. 2003;64:978-91.

40. Yang S, Xiao L, Xu B, Xu X, Liu F, Sun L. Effects of vitamin E-coated dialyzer on oxidative stress and inflammation status in hemodialysis patients: A systematic review and meta-analysis. Ren Fail. 2014;36(5):722-31. 